\title{
DAMPAK MEMBANGUN POLA PENERAPAN PENGELOLAAN KEUANGAN BADAN LAYANAN UMUM DAERAH DI BPSDMD PROVINSI SUMATERA SELATAN
}

\author{
Emmy Deseri ${ }^{1}$ Yuliana $^{2}$ \\ ${ }^{1)}$ Staf pengajar Magister Administrasi Publik Program Pascasarjana \\ Universitas Sjakhyakirti Palembang \\ ${ }^{2)}$ Staf pengajar Magister Administrasi Publik Program Pascasarjana \\ Universitas Sjakhyakirti Palembang \\ Email : emmydeseri63@gmail.com, yuli_72@yahoo.co.id
}

\begin{abstract}
ABSTRAK
Selama ini Badan Pengembangan Sumber Daya Manusia Daerah (BPSDMD) Provinsi Sumsel telah melaksanakan pendidikan dan pelatihan bagi Aparatur Sipil Negara didukung oleh dana Anggaran Pendapatan Belanjar Daerah (APBD) Provinsi, sehingga kinerja maupun volume penyelenggaraan kediklatan sangat terbatas. Apalagi dengan kegiatan Asean Games tahun 2016- 2017 lalu, ditengah rendahnya kinerja dan minimnya alokasi anggaran untuk penyelengaraan pendidikan dan pelatihan maka efisiensi anggaran adalah solusi yang paling akhir. Beberapa kegiatan yang sudah drencanakan tidak dapat dilaksanakan, bahkan sejak tahun 2018 sama sekali tidak ada alokasi dana untuk pelatihan Aparatur Sipil Negara di Provinsi Sumatera Selatan. Penerapan PPK- BLUD berlaku sejak ditetapkan dengan Keputusan Gubemur Nomor 201/KPTS/BPKAD/ 2017 tanggal 17 Maret 2017 dengan status BLUD Penuh. Sebelum menerapkan PPK- BLUD BPSDMD Provinsi Sumsel dalam melaksanakan pendidikan dan pelatihan bagi Aparatur Sipil Negara hanya didukung oleh APBD, sehingga prekuensi penyelenggaraan serta jumlah peserta pelatihan yang dapat dijangkau sangat terbatas. Ditengah minimnya alokasi anggaran untuk pendidikan dan pelatihan dalam APBD Provinsi Sumsel terutama pada tahun 2016 dan tahun 2017 yang mengalami beberapa kali efisiensi sehingga beberapa kegiatan yang sudah direncanakan tidak dapat dilaksanakan, bahkan tahun 2018 sama sekali tidak ada alokasi dana untuk pelatihan Aparatur Sipil Negara. Sejak Pasca penerapan PPK- BLUD BPSDMD Provinsi Sumsel mendapatkan sumber pendanaan benupa jasa layanan dari hasil kerja sama dengan pemerintah Kabupaten/Kota di Sumatera`Selatan, instansi vertikal yang ada di daerah, serta kementerian antara lain Kemenhum HAM, Kemenrisdikti, Mahkamah Agung serta pemerintah provinsi/kabupaten/ kota serta lembaga lainnya dalam melaksanakan kerjasama penyelenggaraan pendidikan dan pelatihan. Hal ini merupakan peluang besar sekaligus sebagai tantangan dalam pengembangan PPKBLUD dalam upaya meningkatkan pelayanan publik
\end{abstract}

Kata Kunci: BPSDMD, Pelatihan ASN, dan pelayanan publik.

\section{PENDAHULUAN}

Badan Pengembangan Sumber Daya Manusia Daerah (BPSDMD) Provinsi Sumsel telah melaksanakan pendidikan dan pelatihan bagi Aparatur Sipil Negara didukung oleh dana Anggaran Pendapatan Belanjar Daerah (APBD) Provinsi, sehingga kinerja maupun volume penyelenggaraan kediklatan sangat terbatas. Apalagi dengan kegiatan Asean Games tahun 2016- 2017 lalu, ditengah rendahnya kinerja dan minimnya alokasi anggaran untuk penyelengaraan pendidikan dan pelatihan maka efisiensi anggaran adalah solusi yang paling akhir. Beberapa kegiatan yang sudah direncanakan tidak dapat dilaksanakan, bahkan sejak tahun 2018 sama sekali tidak ada 
alokasi dana untuk pelatihan Aparatur Sipil Negara di Provinsi Sumatera Selatan. Hasil kajian kongkrit untuk mendorong peningkatan Kinerja adalah melaksanakan Pola Penerapan Pengelolaan Keuangan Badan Layanan Umum Daerah atau yang lebih dikenal dengan istilah (PPK- BLUD) yang merupakan salah satu bentuk dari agenda reformasi di bidang keuangan Negara, khususnya pola penganggaran tradisional menuju pola penganggaran berbasis kinerja, dimana arah penggunaan keuangan tidak lagi berorientasi input tetapi berorientasi kepada output. Dengan keberaniannya Sumsel di tahun 2017 Penerapan PPK- BLUD dan berlaku sejak ditetapkan dengan Keputusan Gubemur Nomor 201/KPTS/BPKAD/ 2017 tanggal 17 Maret 2017 dengan status BLUD Penuh.

Pendekatan penganggaran berbasis kinerja sangat diperlukan bagi pemerintah maupun pemerintah daerah dimana organisasi perangkat daerah yang memberikan pelayanan kepada publik dengan cara mewirausahakan pemerintah (enterprising the government). Maka PPK-BLUD merupakan pengecualian (Previlesse) dalam pengelolaan keuangan pada umumnya. yang memberikan fleksibelitas berupa keleluasaan untuk menerapkan praktik bisnis yang sehat untuk meningkatkan pelayanan kepada masyarakat. Previlesse atau pengecualian yang diberikan dimaksudkan untuk meningkatkan kualitas pelayanan dan produktivitas kinerja yang sifatnya non profit oriented. Sehingga tidak semua perangkat daerah atau unit kerja perangkat daerah dapat menerapkan PPK-BLUD, melainkan hanya organisasi perangkat daerah atau unit kerja perangkat daerah yang tugas pokok dan fungsinya memberikan pelayanan langsung kepada masyarakat atau dalam istilah yang lain disebut Quasi Public Goods, yaitu perangkat daerah yang dalam operasionalnya sebagian dibiayai dari Anggaran Pendapatan dan Belanja Daerah, sebagian lagi dari hasil jasa layanan yang diberikan, namun demikian sifatnya tidak semata-mata mencari keuntungan (not for profit). Penerapan PPK- BLUD berlaku sejak ditetapkan dengan Keputusan Gubemur Nomor 201/KPTS/BPKAD/ 2017 tanggal 17 Maret 2017 dengan status BLUD Penuh. Sebelum menerapkan PPK- BLUD BPSDMD Provinsi Sumsel dalam melaksanakan pendidikan dan pelatihan bagi Aparatur Sipil Negara hanya didukung oleh APBD, sehingga prekuensi penyelenggaraan serta jumlah peserta pelatihan yang dapat dijangkau sangat terbatas. Ditengah minimnya alokasi anggaran untuk pendidikan dan pelatihan dalam APBD Provinsi Sumsel terutama pada tahun 2016 dan tahun 2017 yang mengalami beberapa kali efisiensi sehingga beberapa kegiatan yang sudah drencanakan tidak dapat dilaksanakan, bahkan tahun 2018 sama sekali tidak ada alokasi dana untuk pelatihan Aparatur Sipil Negara.

Sesuai amanat Undang-Undang Nomor 5 Tahun 2014 tentang ASN, bahwa seorang ASN paling tidak mengikuti pendidikan pelatihan $25 \mathrm{jam}$ pelajaran dalam satu tahun, dan Peraturan Pemerintah Nomor 11 Tahun 2017 tentang Manajemen PNS, seorang PNS paling tidak harus memiliki 3 kompetensi yakni, kompetensi Teknis, Manajerial, dan Sosiokultural, untuk mendapatkan kompetensi ini ini salah satunya melalui pendidikan dan pelatihan. 


\section{METODE PENELITIAN}

Penelitian yang digunakan adalah menggunakan pendekatan kualitatif dilihat dari fenomena masalah yang ingin dikaji dengan melihat tingkat ekspalanasinya, sebagaimana yang dikemukakan oleh Miles dan Huberman (1994) mengemukakan pendekatan kualitatif bertujuan untuk menggali atau membangun suatu proposisi atau menjelaskan makna di balik realita.

Adapun yang dijadikan alasan penulis menggunakan metode kualitatif ini, bahwa dianggap lebih mudah menyesuaikan apabila berhadapan dengan kenyataan yang sebelumnya tidak terduga, selain itu peneliti juga bertugas dilingkungan tempat penelitian ini sebagai pegawai Bagian Umum dan Perlengkapan Dinas Pendidikan di Kabupaten Musi Banyuasin, dari segi biaya tidak memerlukan banyak dan dari segi waktu peneliti dapat secara langsung melakukan pengamatan dan dapat berhubungan langsung dengan informan, disamping itu pula metode kualitatif lebih peka terhadap segala pola perubahan nilai yang berlaku. Di dalam pemilihan pendekatan kualitatif untuk menjawab masalah penelitian yang diajukan, lebih menekankan pada Strategi Badan Layanan Umum Daerah (BLUD) Terhadap Pengembangan Sumber Daya Aparatur Pemerintah Di Provinsi Sumatera Selatan

Fokus penelitian ini mengenai Strategi Badan Layanan Umum Daerah (Blud) Terhadap Pengembangan Sumber Daya Aparatur Pemerintah Di Provinsi Sumatera Selatandengan mengacu pada (1) motivasi kerja, (2) kemampuan kerja, (3) suasana kerja, (4) lingkungan kerja, (5) perlengkapan dan fasilitas dan (6) prosedur kerja.
Objek dalam penelitian ini adalah Strategi Badan Layanan Umum Daerah (Blud) Terhadap Pengembangan Sumber Daya Aparatur Pemerintah DiProvinsi Sumatera Selatan.

Data penelitian ini bersumber dari pihakpihak terkait yang berperan dalam memberikan data dan informasi dalam lingakup penelitian dan sarana yang digunakan untuk memperoleh data dan informasi yang berkaitan dengan masalah yang akan diteliti. Dalam hal ini penulis menggunakan dua macam data menurut klasifikasi berdasarkan dari jenis dan sumbernya, yaitu Data Primer, dan Data Sekunder

Dalam penelitianini penulis melakukan observasi atau pengamatan langsung terhadap fenomena atau gejala yang terjadi dilapangan terhadap obyek yang akan diteliti, observasi juga dimaksudkan untuk lebih mengetahui kondisi dilapangan secara mendalam dan proses pelaksanaan kegiatan yang dilakukan oleh obyek secara langsung dan nyata.

Dalam penelitian ini, peneliti menggunakan wawancara yang dilakukan secara mendalam (indepth interview). Dimana wawancara mendalam yaitu melakukan serangkaian tanya jawab antara peneliti dengan informan yang dilakukan secara terbuka dan leluasa. Selanjutnya dalam penelitian ini dokumen berupa studi kepustakaan yakni menelusuri, mengumpulkan, dan mencatat data tertulis dan keterangan ilmiah dari buku-buku, jumal, dan dokumen yang berisikan peraturan-peraturan, hukum-hukum, pendapat-pendapat, dan teori-teori dari para ahli yang berkaitan dengan masalah yang diteliti dan sesuai substansi penelitian. 
Pemilihan informan dilakukan secara purposive yaitu orang yang memiliki pengetahuan cukup dan mampu menjelaskan keadaan yang sebenamya tentang obyek penelitian untuk mendapatkan data yang dibutuhkan.

Adapun informan adalah sebagai berikut:

1. Implementor : Kepala Badan BPSDMD

Provinsi Sumsel, Bagian Perencanaan, Kepala Keuangan .Kepada BPSDMD Kabupaten/Kota

2.KelompokSasaran : Kepada BPSDMD Kabupaten/Kota

Penelitian yang dilakukan dengan menggunakan strategi Triangulasi. Strategi Triangulasi diperlukan untuk memastikan bahwa proses penelitian dari studi kasus yang dilakukan sudah sesuai atau valid. Validitas proses penelitian dari studi kasus menjadi penting untuk menghindari hasil penelitian yang diragukan reliabilitasnya atau subjektifitas peneliti yang berlebihan.

Proses Triangulasi dalam penelitian ini lakukan dengan menggunakan Triangulasi Sumber. Triangulasi ini dilakukan dengan membandingkan dan mengujikan derajat kebenaran atau validitas suatu informasi yang diperoleh melalui waktu dan alat yang berbeda dalam penelitian kualitatif. Hal itu dilakukan dengan jalan: (1) membandingkan data hasil pengamatan dengan data hasil wawancara yang dilakukan oleh penelit;; (2) membandingkan pemyataan informan yang disampaikan di depan umum dengan yang apa yang disampaikan oleh informan tersebut secara pribadi; membandingkan apa yang disampaikan oleh orang-orang tentang situasi penelitian dengan apa yang disampaikan dalam kurun waktu tertentu; (4) membandingkan keadaan dan perspektif seseorang dengan berbagai pendapat dan pandangan pihak lain seperti pegawai yang mempunyai hubungan keterkaitan dengan bagian umum dan perlengkapan. (5) membandingkan hasil wawancara dengan dokumen yang mendukung atau berkaitan .

Teknik Analisa data dilakukan setelah pengumpulan data dilaksanakan, yang dilanjutkan dengan mereduksi data yaitu proses pemilahan terhadap data yang diperoleh dilapangan, dimana data yang diperoleh melalui wawancara, observasi atau pengamatan yang sudah ditentukan dalam catatan lapangan, dokumen, gambar, dan lain-lain dipilah serta diambil inti dari data tersebut untuk disesuaikan dengan keperluan penelitia, reduksi data yang dilakukan dengan jalan membuat abstraksi. Selanjutnya adalah menyusun dalam satuan-satuan. Satuan itu dikategorikan pada langkah berikutnya. Kategori-kategori dilakukan sambil membuat penandaan (koding) yang akhimya mengadakan pemeriksaan kembali keabsahan hingga ke tahap penafsiran data. tahap selanjutnya adalah menyajikan data yang diperoleh dan pada akhirnya dihasilkan suatu kesimpulan, seperti analisis data yang dilakukan terhadap Strategi Badan Layanan Umum Daerah (BLUD) Terhadap Pengembangan Sumber Daya Aparatur Pemerintah Di Provinsi Sumatera Selatan. 


\section{HASIL DAN PEMBAHASAN}

Kiprah BPSDMD Provinsi Sumatera Selatan dari Tahun 2014 s.d 2018 telah melakukan pendidikan dan pelatihan bagi aparatur sebanyak 4.998 orang, yang meliputi pengembangan kompetensi teknis, fungsional, pemerintahan dan politik serta manajerial/kepemimpinan.

Pada Tahun 2014, BPSDMD Provinsi Sumatera Selatan melaksanakan kegiatan diklat sebanyak 19 jenis diklat (22 angkatan) dengan total peserta berjumlah 810 orang, Tahun 2015 melaksanakan kegiatan diklat 17 jenis diklat (22 angkatan) dengan total jumlah peserta 884 orang dan pada Tahun 2016 melaksanakan 12 jenis diklat (18 angkatan) dengan total jumlah peserta 727 orang, Tahun 2017 melaksanakan kegiatan kediklatan dengan jumlah peserta sebanyak 1308 orang dan Tahun 2018 melaksanakan kegiatan kediklatan dengan jumlah peserta diklat 1.269 orang.

\section{Keberhasilan kebijakan berdampak bagi Stakeholder}

Keberhasilan implementasi penerapan PPK-BLUD berdampak positif bagi stakeholder dalam hal ini BPSDMD Provinsi Sumatera Selatan, yaitu antara lain sebagai berikut:

1. Pendapatan BLUD yang berasal dari jasa layanan dapat langsung digunakan tanpa harus masuk dulu dalam kas daerah.

2. Flexible budget, dalam pelaksanaan belanja BLUD dapat melampaui pagu yang telah ditetapkan.

3. BLUD dapat melakukan hutang/piutang, investasi, dan kerjasama atas persetujuan Gubemur.
4. Dalam pengadaan barang/jasa, dapat diberikan fleksibelitas sepanjang sumber dananya berasal dari jasa layanan, hal ini dimaksudkan untuk percepatan proses namun tetap dengan prinsip efisien, efektif, transparan, bersaing, adil/tidak diskriminatif, akuntabel.

5. BLUD dapat menghapus aset tidak tetap, aset-aset yang sudah tidak produktif atau sudah tidak efisien lagi, hasilnya menupakan pendapatan BLUD.

6. Tarif layanan BLUD ditetapkan dengan Peraturan Gubemur, hal ini dimaksudkan untuk percepatan proses dan efisiensi, namun penetapan tarif harus mempertimbangkan kontinuitas dan pengembangan layanan, daya beli masyarakatserta kompetisi yang sehat.

Keberhasilan kebijakan yang berdampak bagi individu

1. Pejabat pengelola BLUD pegawai BLUD dapat diberikan remunerasi/ honorarium sesuai dengan tanggung jawab dan kinerjanya berdasarkan kemampuan keuangan BLUD.

2. Pejabat Pengelola dan pegawai BLUD dapat diangkat dari PNS dan non PNS sesuai ketentuan yang berlaku.

3. Dengan meningkatnya prekwensi penyelenggaraan pelatihan maka terbuka kesempatan yang lebih luas bagi Aparatur Sipil Negara untuk mengikuti pelatihan yang diselenggarakan oleh BPSDMD Provinsi SumateraSelatan. 
Keberhasilan kebijakan yang berdampak bagi kelompok

Keberhasilan kebijakan berdampak bagi kelompok apabila PPK - BLUD dapat memberikan layanan publik yang lebih profesional, efektif, sederhana, transparan, terbuka, tepat waktu, responsif dan adaptif serta sekaligus dapat membangun kualitas manusia dalam arti meningkatkan kapasitas bagi kelompok untuk secara aktif menentukan masa depannya sendiri. Pelayanan publik yang profesional setidaknya didasarkan pada akuntabilitas, dan responsibilitas dari pemberi layanan (aparatur pemerintah) melalui penguatan pranata pelayanan dengan lebih mengedepankan efektivitas pada pencapaian apa yang menjadi tujuan dan sasaran, sederhana dalam prosedur dan tata cara pelayanan yang diselenggarakan secara mudah, cepat, tepat, tidak berbelit-belit, mudah dipahami dan mudah diakses oleh masyarakat pengguna jasa pelayanan.

\section{REKOMENDASI}

Penerapan PPK-BLUD tidak hanya sekedar mengejar fleksibelitas dalam pengelolaan keuangan semata, tetapi kewenangan penerapan PPK-BLUD diberikan untuk meningkatkan kinerja pelayanan, kinerja manfaat, dan kinerja keuangan, dengan tidak semata-mata berorientasi untuk mengejar keuntungan (profit oriented). Oleh sebab itu dalam upaya peningkatan kinerja BLUD BPSDMD Provinsi Sumatera Selatan, direkomendasikan 3 hal sebagai berikut, yaitu:

1. Meningkatkan pemahamam dan perubahan pola pikir (maindset) semangat kewirausahaan (enterpreneurshif) terutama bagi pejabat pengelola Badan Layanan Umum Daerah BPSDMDProvinsi Sumatera Selatan.

2. Dalam upaya meningkatkan kinerja Badan Layanan Umum Daerah perlu didukung dengan sarana prasarana pendidikan dan pelatihan yang cukup memadai, hal ini sebagai upaya peningkatan daya saing BPSDMD Provinsi SumateraSelatan.

3. Perlu peningkatan kapasitas dan profesionalisme Widyaiswara sebagai tenaga pengajar pendidik dan pelatih (Dikjartih) secara berkesinambungan sebagai komponen utama dalam pelaksanaan pelatihan.

4. Perlunya meningkatkan sarana dan parasaram BLUD dalam melaksanakan Pola PPK BLUD

5. Perlunya meningkatkan koordinasi dengan stakeholder dalam meningatkan target PAD yang telah ditetapkan setiap tahunnya,

\section{DAFTAR PUSTAKA}

Agustino, Leo. 2006. Dasar-Dasar kebijakan Publik, CV. Alfabeta, Bandung.

Atmosoeprapto, 2000, Manajemen SDM /Personil/Kepegawaian, ElexMedia Komputindo, Jakarta

Devis Keith dan Newstrom John, 1989. Perilaku Dalam Organisasi. Diterjemahkan Agus Darma Jakarta. Erlangga

Willim N, 1997. Pengantar Analisis Kebijakan Publik (terjemahan) Gadjah Mada University Press. Yogyakarta.

Edward III, George. 1980. Implementing Public Policy, Washington D.C. Cogresional Quarterly Pre 